\title{
Tomato productivity depending on mineral nutrition and irrigation regimes in the conditions of film greenhouses in the mountain zone of the KBR
}

\author{
Zalim-Geri Shibzukhov ${ }^{1, *}$, Artur Bagov $^{2}$, Zalina Shibzukhova ${ }^{1}$, Martin Khantsev ${ }^{1}$, and \\ Ilakhun $\mathrm{Akbar}^{3}$ \\ ${ }^{1}$ Kabardino-Balkarian State Agricultural University named after V.M. Kokov, Lenin Avenue, 1V, \\ 360030 Nalchik, Russia \\ ${ }^{2}$ Kabardino-Balkarian State University named after H.M. Berbekov, st. Chernyshevskogo, 173, \\ 360004 Nalchik, Russia \\ ${ }^{3}$ Xinjiang University, Nongda East Road, 311, 830052 Urumqi, People's Republic of China
}

\begin{abstract}
The limited irrigation areas in the KBR, as well as the lack of a clear technology for the cultivation of this crop in film greenhouses using irrigation regimes and mineral fertilizers strongly affect the development and production of early tomatoes. In this regard, our research was devoted to the cultivation of tomatoes under irrigation conditions with the selection of the optimum doses of mineral fertilizers in spring film greenhouses. In the KBR settlements, vegetable crops are mainly grown in film greenhouses, which have numerous advantages over block greenhouses, mainly due to the cheapness of production several times over. Tomato seedlings were planted on April 10. Analysis of the data showed that the duration of the growing season increases on variants with optimum water and nutrient regimes of the soil, which led to higher quality products. This created favorable conditions for greater productivity of tomato fruits. Studies showed that the number of fruits and their weight on one plant were maximum according to the variants of the experiment on soil moisture content of $80 \%$ of normal moisture. The maximum value was obtained with a dose of mineral nutrition $\mathrm{N}_{190} \mathrm{P}_{160} \mathrm{~K}_{120}$.
\end{abstract}

\section{Introduction}

"In modern Russia, the share of vegetable production does not exceed 5\% of the total volume of their production. The construction of film greenhouses is promising for the development of greenhouse vegetable growing in modern agro-economic conditions. These facilities are 2 times cheaper than stationary ones in terms of cost and in the conditions of spring crop rotation consume 4-5 times less energy and are able to ensure high yields of valuable, highly profitable vegetable crops" [2].

\footnotetext{
* Corresponding author: konf07@mail.ru
} 
"The issues of development and application of new technologies for tomato cultivation in spring film greenhouses are very relevant and timely. It is necessary to qualitatively enhance the technology of growing crops, considering the fuller use of available natural and technical resources, the biological potential of productivity of varieties and hybrids in spring film greenhouses, as the most dynamic industry in modern Russia" [1].

Tomato is the KBR leading vegetable crop. "The value of growing early tomatoes is that they open up the supply of fortified outdoor products to the market. The production of early products, despite the additional material and labor costs, has a number of advantages and is economically feasible" [3].

"The restraining factors for the development of early tomato production using drip irrigation systems are the limited areas of irrigation by such systems and the lack of technology for growing this crop in film greenhouses, consistent with the peculiarities of water distribution over the irrigated area" [4].

In this regard, our research was devoted to the cultivation of tomatoes under irrigation conditions with the selection of the optimum doses of mineral fertilizers in spring film greenhouses.

Research purpose: optimization of the spring film greenhouse technology of growing tomatoes.

To achieve these goals, the following tasks were solved:

1. Establish the effect of drip irrigation on the growth, development and productivity of tomato crops, depending on irrigation rates and doses of mineral fertilizers;

2. Perform an economic analysis of the cultivation of early production of tomato fruits on various modes of irrigation and mineral nutrition.

The scientific novelty of the research consists in the optimization of the water balance of the soil, the introduction of a sufficient amount of mineral fertilizers to obtain the highest yield in the conditions of film greenhouses in the mountainous zone of the KBR.

Objects of research. Laboratory analyzes for the research were performed at the FSBI "SAS" Kabardino-Balkarskaya". The F1 Verlioka tomato cultivar was used. Drip irrigation is standard for plastic greenhouses. In the experiments, the following mineral fertilizers were used: nitrogen supply - ammonium sulfate, ammophos; phosphorus supply superphosphate, ammophos; potassium supply - potassium sulfate.

\section{Research methodology and conditions}

The agricultural techniques in the experiments were developed on the basis of the current zonal recommendations with additions to their variants of the studied methods. The grown 40-day-old seedlings at the time of planting in the ground had a height of $25-30 \mathrm{~cm}$ with the flowers of the first cluster. Seeds were sown on March 5. Seedlings were planted in the greenhouse from 5 to 10 April.

The mathematical analysis of the obtained experimental data was performed according to B.A. Dospekhov's method.

The experiment scheme provided for the following options for the irrigation regime:

1. Maintaining soil moisture in the $0.4 \mathrm{~m}$ layer at $70 \%$ of normal moisture;

2. Maintaining soil moisture in the $0.4 \mathrm{~m}$ layer at $80 \%$ of normal moisture;

3. Maintaining soil moisture in the $0.4 \mathrm{~m}$ layer at $90 \%$ of normal moisture.

The calculation of the irrigation rate was performed in accordance with the research methodology.

Experiment scheme for doses of mineral fertilizers:

1. Application of mineral fertilizers in the application rate of $\mathrm{N}_{90} \mathrm{P}_{60} \mathrm{~K}_{60}$;

2. Application of mineral fertilizers in the application rate of $\mathrm{N}_{140} \mathrm{P}_{110} \mathrm{~K}_{90}$;

3. Application of mineral fertilizers in the application rate of $\mathrm{N}_{190} \mathrm{P}_{160} \mathrm{~K}_{120}$. 
When calculating the doses of fertilizers, we relied on the recommendations for growing tomatoes in film greenhouses in literary sources, calculations for the removal of mineral elements by tomato plants and the background of the soil.

The experiments were repeated four times, randomized. The area of accounting plots for all options amounted to $100 \mathrm{~m}^{2}$.

The experiments were performed in film greenhouses located in the Baksan district of the KBR in the village of Kishpek, at the LLC "Agro-K" enterprise ( 850 meters above sea level).

\section{Results and Discussion}

"The duration of the growing season, during which the tomato goes through differentquality phases of development, is one of the important criteria for assessing the conditions for the formation of the tomato fruit harvest. Their timing and the duration of interphase periods are usually significantly influenced by meteorological conditions, biological characteristics of the variety and cultivation technology" [4].

In our studies, the timing of the stages of development of tomato plants and the duration of interphase periods in different years are presented in Table 1.

Table 1. The influence of the timing of the onset of the phases of development of tomatoes from the introduction of mineral fertilizers and irrigation regimes.

\begin{tabular}{|c|c|c|c|c|c|c|}
\hline $\begin{array}{c}\text { Mineral } \\
\text { fertilizer doses } \\
\text { (kg of } \\
\text { application } \\
\text { rate/ha) }\end{array}$ & $\begin{array}{c}\text { Humidity } \\
\text { \% of normal } \\
\text { moisture) }\end{array}$ & $\begin{array}{c}\text { Seedling } \\
\text { planting } \\
\text { date }\end{array}$ & $\begin{array}{c}\text { Flowering } \\
\text { date }\end{array}$ & $\begin{array}{c}\text { Start date } \\
\text { of fruiting }\end{array}$ & $\begin{array}{c}\text { Fruiting } \\
\text { date }\end{array}$ & $\begin{array}{c}\text { Date of last } \\
\text { harvesting }\end{array}$ \\
\hline \multirow{3}{*}{$\mathrm{N}_{90} \mathrm{P}_{60} \mathrm{~K}_{60}$} & 70 & 10.04 & 19.04 & 01.05 & 08.06 & 15.09 \\
\cline { 2 - 7 } & 80 & 10.04 & 20.04 & 01.05 & 10.06 & 19.09 \\
\cline { 2 - 7 } & 90 & 10.04 & 20.04 & 02.05 & 09.06 & 18.09 \\
\hline \multirow{3}{*}{$\mathrm{N}_{140} \mathrm{P}_{110} \mathrm{~K}_{90}$} & 70 & 10.04 & 19.04 & 03.05 & 10.06 & 22.09 \\
\cline { 2 - 7 } & 90 & 10.04 & 21.04 & 05.05 & 14.06 & 25.09 \\
\hline \multirow{3}{*}{$\mathrm{N}_{190} \mathrm{P}_{160} \mathrm{~K}_{120}$} & 70 & 10.04 & 21.04 & 09.05 & 12.06 & 21.09 \\
\cline { 2 - 7 } & 90 & 10.04 & 20.04 & 08.05 & 13.06 & 27.09 \\
\hline
\end{tabular}

Tomato seedlings were planted on April 10. The table shows that the variants with optimum water and nutrient regimes of the soil had the increased duration of the vegetation. This created favorable conditions for greater productivity of tomato fruits.

Studies showed that the number of fruits and their weight on one plant were maximal according to the variants of the experiment on soil moisture content of $80 \%$ of normal moisture. The maximum value was obtained with a dose of mineral nutrition $\mathrm{N}_{190} \mathrm{P}_{160} \mathrm{~K}_{120}$ (Tab. 2).

Table 2. Tomato yield structure depending on mineral nutrition and irrigation regime.

\begin{tabular}{|c|c|c|c|c|}
\hline $\begin{array}{c}\text { Mineral } \\
\text { fertilizer } \\
\text { doses } \\
\text { (kg of } \\
\text { application } \\
\text { rate/ha) }\end{array}$ & $\begin{array}{c}\text { Pre-irrigation } \\
\text { humidity } \\
\text { (\% of normal } \\
\text { moisture) }\end{array}$ & $\begin{array}{c}\text { Number of } \\
\text { fruits per plant } \\
\text { (pcs.) }\end{array}$ & $\begin{array}{c}\text { Fruit weight } \\
\text { per plant } \\
(\mathrm{kg})\end{array}$ & $\begin{array}{c}\text { Weight } \\
\text { of one } \\
\text { fruit } \\
(\mathrm{kg})\end{array}$ \\
\hline \multirow{2}{*}{$\mathrm{N}_{90} \mathrm{P}_{60} \mathrm{~K}_{60}$} & 70 & 24.2 & 3.45 & 0.151 \\
\cline { 2 - 5 } & 80 & 26.5 & 3.74 & 0.159 \\
\cline { 2 - 5 } & 90 & 25.4 & 3.65 & 0.154
\end{tabular}


Table 2. Continued.

\begin{tabular}{|c|c|c|c|c|}
\hline \multirow{3}{*}{$\mathrm{N}_{140} \mathrm{P}_{110} \mathrm{~K}_{90}$} & 70 & 30.7 & 4.22 & 0.162 \\
\cline { 2 - 5 } & 80 & 33.4 & 4.74 & 0.167 \\
\cline { 2 - 5 } & 90 & 31.8 & 4.56 & 0.164 \\
\hline \multirow{3}{*}{$\mathrm{N}_{190} \mathrm{P}_{160} \mathrm{~K}_{120}$} & 70 & 36.5 & 5.34 & 0.166 \\
\cline { 2 - 5 } & 80 & 39.6 & 5.78 & 0.171 \\
\cline { 2 - 5 } & 90 & 37.6 & 5.59 & 0.169 \\
\hline
\end{tabular}

In experiments, with an increase in the soil moisture threshold from 60 to $90 \%$ of normal moisture, the number of fruits increased by 2.2-3.5 pcs. The irrigation regime also influenced the weight of the fruits, with an increase in humidity, it increased.

Ensuring the quality products is an important condition for growing any agricultural crops. The special value of tomato fruits is given by their chemical composition, what chemicals are present in it, in what quantity, etc.

"The soil, climatic and weather conditions, varietal characteristics, growing conditions and other conditions affect the content of nutrients in tomato fruits. Irrigation and fertilization are among the most efficient factors contributing to improving the quality of the tomato crop" [5].

Table 3. Changes in the chemical composition of tomato fruits depending on the mineral nutrition and irrigation regime.

\begin{tabular}{|c|c|c|c|c|c|c|}
\hline \multirow{2}{*}{$\begin{array}{c}\text { Doses of mineral } \\
\text { fertilizers (kg of } \\
\text { application rate/ha) }\end{array}$} & $\begin{array}{c}\text { Humidity (IH } \\
\%)\end{array}$ & \multicolumn{5}{|c|}{ Chemical composition of tomato fruits } \\
\hline \multirow{3}{*}{$\mathrm{N}_{90} \mathrm{P}_{60} \mathrm{~K}_{60}$} & 70 & 6.41 & 0.62 & 3.8 & 0.58 & 51.7 \\
\cline { 2 - 7 } & 80 & 6.35 & 0.66 & 3.7 & 0.59 & 49.3 \\
\cline { 2 - 7 } & 90 & 6.75 & 0.55 & 4.2 & 0.56 & 63.9 \\
\hline \multirow{3}{*}{$\mathrm{N}_{140} \mathrm{P}_{110} \mathrm{~K}_{90}$} & 70 & 6.14 & 0.65 & 3.6 & 0.61 & 64.2 \\
\cline { 2 - 7 } & 80 & 6.07 & 0.71 & 3.4 & 0.62 & 61.4 \\
\hline \multirow{3}{*}{$\mathrm{N}_{190} \mathrm{P}_{160} \mathrm{~K}_{120}$} & 90 & 6.49 & 0.60 & 3.9 & 0.59 & 78.1 \\
\cline { 2 - 7 } & 70 & 5.91 & 0.74 & 3.3 & 0.64 & 74.3 \\
\cline { 2 - 7 } & 90 & 5.82 & 0.79 & 3.2 & 0.66 & 71.6 \\
\hline
\end{tabular}

Data analysis (Table 3) showed that in variants with a dose of $\mathrm{N}_{190} \mathrm{P}_{160} \mathrm{~K}_{120}$, the nitrate content in fruits is maximum and ranges within $74.3-90.8 \mathrm{mg} / \mathrm{kg}$, depending on the irrigation regime. An increase in the moisture content of the soil in some cases led to an increase in sugar in tomato fruits. A decrease in the content of nitrates was observed in the $80 \%$ of normal moisture variants. The content of nitrates for all variants of the experiments did not exceed the permissible limits.

"The most important parameter for assessing the efficiency of the technological process of sectoral agricultural production is the optimization criterion, that is, the parameter by which the object under study is evaluated and with which all the factors under study are linked into a single complex" [4].

"Indicators characterizing the economics of the functioning of production have a certain degree of importance in evaluating the efficiency of the technological process of cultivation of agricultural crops and the feasibility of using, reclamation agricultural practices" [3].

The feasibility of the technology was determined by the cost of gross production, items of expenditure for the full turnover of growing tomato plants. The average price of the product was taken for the entire vegetation (Table 4). 
Table 4. Feasibility of growing tomato depending on mineral nutrition and irrigation regime.

\begin{tabular}{|c|c|c|c|c|c|c|}
\hline $\begin{array}{c}\text { Mineral } \\
\text { fertilizer doses } \\
\text { (kg of } \\
\text { application } \\
\text { rate/ha) }\end{array}$ & $\begin{array}{c}\text { Soil moisture } \\
\text { content } \\
\text { \% of normal } \\
\text { moisture) }\end{array}$ & Yield (t/ha) & $\begin{array}{c}\text { Expenses, } \\
\text { (RUR } \\
\text { th/ha) }\end{array}$ & $\begin{array}{c}\text { Prime cost (RUR } \\
\text { th/ha) }\end{array}$ & $\begin{array}{c}\text { Revenue } \\
\text { (RUR } \\
\text { th/ha) }\end{array}$ & $\begin{array}{c}\text { Net } \\
\text { income } \\
\text { (RUR } \\
\text { th/ha) }\end{array}$ \\
\hline \multirow{2}{*}{$\mathrm{N}_{90} \mathrm{P}_{60} \mathrm{~K}_{60}$} & 70 & 93.2 & 331.4 & 3.7 & 1025 & 693.6 \\
\cline { 2 - 7 } & 80 & 104.7 & 340.2 & 3.9 & 1151 & 810.8 \\
\hline \multirow{3}{*}{$\mathrm{N}_{140} \mathrm{P}_{110} \mathrm{~K}_{90}$} & 90 & 100.2 & 348.9 & 3.8 & 1102 & 753.1 \\
\cline { 2 - 7 } & 70 & 111.5 & 399.8 & 3.4 & 1226 & 826.2 \\
\hline \multirow{2}{*}{$\mathrm{N}_{190} \mathrm{P}_{160} \mathrm{~K}_{120}$} & 80 & 131.4 & 410.5 & 3.5 & 1489 & 1078.5 \\
\cline { 2 - 7 } & 90 & 125.6 & 419.7 & 3.6 & 1381 & 961.3 \\
\cline { 2 - 7 } & 90 & 134.7 & 476.5 & 4.1 & 1415 & 938.5 \\
\hline
\end{tabular}

With the increase in the doses of mineral fertilizers to $\mathrm{N}_{190} \mathrm{P}_{160} \mathrm{~K}_{120}$ and soil moisture to $90 \%$ of normal moisture, growing tomatoes required 495.9 RUR th/ha, this is the greatest value among other options, while the net income amounted to about 984.1 RUR th. Thus, at lower costs of 487.4 RUR th/ha on the same variant with fertilizers and moisture content of $80 \%$ of normal moisture, the net income level was about 1,054.6 RUR th, which is by 70.5 RUR th more.

With an optimum ration, with a humidity of $80 \%$ of normal moisture, expenses were about 410.5 RUR th/ha, and a net income amounted to 1,078.5 RUR th.

In real conditions, there is no ideal technology that would satisfy all the qualitative and quantitative indicators of production. We may only optimize some of the technological parameters to obtain the desired product in a certain quantity with the economic component of the manufactured product.

\section{Conclusions}

1. To maintain soil moisture in the $0.5 \mathrm{~m}$ layer at a level of $60-80 \%$ of normal moisture, 10 to 25 irrigations should be performed with an irrigation rate of $200-300 \mathrm{~m}^{3} / \mathrm{ha}$.

2. The timing of the phases depended on the irrigation regimes and the application of doses of mineral fertilizers. The higher the irrigation rate and the higher the amount of applied fertilizer, the more the phase-to-phase periods increased.

3. Analysis of the yield structure showed that with an increase in the soil moisture threshold from 60 to $90 \%$ of normal moisture, the number of fruits increased by 2.2-3.5 pcs. The irrigation regime also influenced the weight of the fruits, with an increase in humidity it increased, and the indicators also increased in proportion to the application of mineral fertilizers.

4. The obtained chemical composition data showed that in variants with a maximum dose of $\mathrm{N}_{190} \mathrm{P}_{160} \mathrm{~K}_{120}$, the content of nitrates in fruits is correspondingly maximum and, depending on the irrigation regime, ranges within $74.3-90.8 \mathrm{mg} / \mathrm{kg}$. The amount of nitrates for all items did not exceed the permissible environmental standards.

5. The greatest economic effect according to the variants of the experiments was obtained with a moisture supply mode of $80 \%$ of normal moisture with a dose of mineral nutrition $\mathrm{N}_{140} \mathrm{P}_{110} \mathrm{~K}_{90}$, where the net income per hectare was 1,078.5 RUR th. 


\section{References}

1. A. K. Yezaov, Z. S. Shibzukhov, M. Kh. Nagoyev, Modern problems of science and education, 1(1), 1693 (2015)

2. A. K. Yezaov, Z. S. Shibzukhov, Current ecological state of the environment and scientific and practical aspects of rational environmental management: The II international scientific and practical Internet conf., 625-629 (2017)

3. Yu. B. Khushtov, Z. S. Shibzukhov, M. Kh. Indarokov, Current ecological state of the environment and scientific and practical aspects of rational environmental management: The II international scientific and practical Internet conf., FSBSI, 613615 (2017)

4. Z. G. S. Shibzukhov, F. M. Kurzhiyeva, Innovative technologies for agrarian and industrial complex of the South of Russia: Materials of the All-Russian academic and research conf., 209-213 (2016)

5. Z. S. Shibzukhov, F. M. Kurzhiyeva, Current ecological state of the environment and scientific and practical aspects of rational environmental management: The I International scientific and practical Internet conf., 2130-2132 (2016)

6. Z. G. S. Shibzukhov, A. K. Yezaov, A. A. Shugushkhov, News of the KabardinoBalkarian state agricultural university named after V. M. Kokov, 2(12), 27-32 (2016)

7. A. Ezov, Z.-G. Shibzukhov, B. Beslaneev, Z. Shibzukhova, M. Khantsev, Int. Scientific and Practical Conf. «Development of the Agro-lndustrial Complex in the Context of Robotization and Digitalization of Production in Russia and Abroad» (2020)

8. K. Nazranov, E. Didanova, Z.-G. Shibzukhov, M. Orzalieva, B. Nazranov, Int. Scientific and Practical Conf. «Development of the Agro-lndustrial Complex in the Context of Robotization and Digitalization of Production in Russia and Abroad» (2020)

9. M. S. Sidakova, E. N. Didanova, A. Y. Kishev, R. Z. Abdulkhalikov, Int. Scientific and Practical Conf. «Development of the Agro-lndustrial Complex in the Context of Robotization and Digitalization of Production in Russia and Abroad» (2020) 